\title{
HUBUNGAN ANTARA MOTIVASI KERJA DENGAN KOMITMEN TERHADAP ORGANISASI GURU GUGUS II KECAMATAN CIPAYUNG DEPOK
}

\author{
Nur Hikmah ${ }^{\left.a^{*}\right)}$ \\ ${ }^{a)}$ Universitas Pakuan, Bogor, Indonesia \\ *e-mail korespondensi : nurhikmahunpak@gmail.com
}

Riwayat Artikel : diterima: 05 Februari 2020; direvisi: 16 Februari 2020; disetujui: 20 Februari 2020

\begin{abstract}
Abstrak. Penelitian ini termasuk ke dalam penelitian korelasi (hubungan) yang terdiri atas satu variabel bebas yaitu Motivasi Kerja (X) dengan satu variabel terikat yaitu Komitmen Terhadap Organisasi (Y). Hipotesis penelitian ini adalah : Terdapat hubungan yang positif antara Motivasi Kerja dengan Komitmen Terhadap Organisasi. Penelitian dilaksanakan di kecamatan Cipayung Kota Depok Jawa Barat Indonesia. Dari total populasi guru berjumlah 104 orang, maka diambil sebanyak 82 orang guru sebagai total sampel yang dipilih secara acak. Metode pengambilan data penelitian di lapangan menggunakan metode survey sementara itu metode statistik analisis data menggunakan teknik analisis korelasi, analisis regresi sederhana. Pengukuran hipotesis diambil baik pada taraf signifikansi $\alpha=0,05$ maupun pada taraf signifikansi $\alpha=0,01$.Berdasarkan dari hasil-hasil perhitungan didapat hasil penelitian yaitu : terdapat hubungan positif yang sangat signifikan antara Motivasi Kerja dengan Komitmen terhadap organisasi dengan persamaan regresi yaitu $\hat{Y}=96,16+0,36$ X, koefisien korelasi $\left(r_{y}\right)$ sebesar 0,411, dan koefisien determinasi $\left(r_{\mathrm{y}}{ }^{2}\right)$ sebesar 0,169 atau 16,9.Berdasarkan hasil perhitungan tersebut diatas maka dapat diambil kesimpulan bahwa Motivasi kerja dapat ditingkatkan melalui Komitmen Terhadap Organisasi..
\end{abstract}

Kata Kunci: motivasi kerja; komitmen terhadap organisasi

\begin{abstract}
RELATIONSHIP BETWEEN MOTIVATION WITH ORGANIZATIONAL COMMITMENT
Abstract. This research is classified into a correlational research which consists of one independent variable, Motivation $(\mathrm{X})$ with one dependent variable, Organization Commitment (Y). The hypothesis of the research is: There is a positive correlation between motivation and organization commitment. This research was conducted in Cipayung, Depok, West Java, Indonesia. The population of 104 teacher, and randomly selected as sample 82 teachers. The method of collecting research data in the field uses the survey method while the statistical method of data analysis uses correlation analysis techniques, simple regression analysis. Hypothesis measurement is taken both at the significance level $\alpha=0.05$ and at the significance level $\alpha=0.01$. Based on the calculation results, the research results are obtained: there is a very significant positive relationship between Motivation with organization commitment with the regression equation that is $\hat{\mathrm{Y}}=96.16+0.36 \mathrm{X}$, the correlation coefficient $\left(\mathrm{r}_{\mathrm{y}}\right)$ of 0.411 , and the coefficient of determination $\left(\mathrm{r}_{\mathrm{y}}{ }^{2}\right)$ of 0.169 or 16.9. Based on the above calculation results, it can be concluded that motivation can be increased through organization commitment
\end{abstract}

Keywords: motivation; organizational commitment

\section{PENDAHULUAN}

Sekolah adalah lembaga sosial yang tumbuh dan berkembang untuk masyarakat dan sekolah juga merupakan suatu organisasi yang terikat terhadap aturan formal yang memiliki program, target dan sasaran yang jelas. Pendidikan sekolah pada dasarnya adalah pendidikan bagian dari keluarga dimana didalamnya terdapat hubungan yang erat antara guru dan anak didik. Guru sebagai pengganti orang tua saat di sekolah berkewajiban membawa anak didik kearah pendewasaan dalam membentuk kepribadian anak. Oleh karena itu, guru harus memiliki komitmen tehadap sekolah untuk bertanggung jawab kepada sekolah, profesi dan anak didiknya.

Komitmen seorang guru dapat mempengaruhi maju mundurnya sekolah. Menurut Wibowo [1], komitmen organisasi adalah kecendurungan merespons pergeseran dramatis pada lingkungan yang bekerja berdasarkan rutinitas organisasi didasari dengan nilai-nilai yang menghubungkan perilaku masa depan. Seorang guru yang mengajar pada jenjang Sekolah dasar tentu harus memiliki pengalaman dan jiwa yang mencintai anak-anak. Metode yang paling tepat dalam mendidik dan mengajar melalui pembiasaan dan keteladanan. Hal ini menjadikan sekolah memerlukan guru yang berpengalaman dan profesional dalam menghadapi berbagai latarbelakang anak secara masing-masing individu. Oleh karena itu, sekolah perlu membangun komitmen guru terhadap sekolah guna menghasilkan anak didik yang berkualitas. Prayitno [2] menyatakan bahwa Komitmen ini didukung oleh faktor : (a) Dedikasi, merupakan wujud tindakan yang didasarkan pada komitmen yang telah diikrarkan (dalam hati), (b) Tanggung Jawab, merupakan tindakan dedikatif yang dilandasi komitmen disertai aspek positif yang sangat penting. Hal senada dengan pandangan Robbins dan Judge [3] bahwa ada tiga dimensi dalam komitmen organisasi diantara: (a) Komitmen afektif, Perasaan emosional untuk organisasi dan keyakinan dalam nilai-nilainya, (b) Komitmen kontinu adalah nilai ekonomi yang dirasa dari bertahan dalam suatu organisasi bila dibandingkan dengan meninggalkan organisasi tersebut, (c) Komitmen normatif adalah kewajiban untuk bertahan dalam 
organisasi untuk alasan-alasan moral atau etis. Sehingga komitmen seorang guru dalam melaksanakan tanggung jawabnya sangat mempengaruhi motivasi kerja dan loyalitas sehingga dapat berpengaruh terhadap kualitas sekolah. Guru yang memiliki komitmen berkeinginan yang kuat untuk melaksanakan tugas dengan kemauan yang kuat pula untuk mempertahankan citra sekolah dan berusaha mempertahankan kualitas pendidikan. Komitmen guru terhadap sekolah akan lebih kuat apabila konsisten dengan harapan-harapan dan memuaskan kebutuhan dasarnya. Senada dengan pendapat Luthans [4], bahwa komitmen organisasi diantaranya: (a) keinginan yang kuat untuk tetap bertahan sebagai anggota organisasi tertentu, (b) kemauan menunjukan tingkat usaha yang tinggi atas nama organisasi, (c) keyakinan yang pasti serta penerimaan atas tujuan dan nilai-nilai organisasi. Sejalan dengan Kreitner, et al, [5] menyatakan komitmen organisasi adalah sebuah tingkatan yang mengidentifikasi individu dengan organisasi dan menjalankannya sampai dengan kesuksesan. Dengan faktorfaktor pendukungnya adalah: (a) Komitment afektif, (b) Komitmen berkelanjutan, (c) Komitmen normatif. Hal ini merupakan salah satu sikap kerja yang penting karena diharapkan setiap guru dapat berkomitmen untuk menampilkan kemauan dalam bekerja lebih keras untuk mencapai tujuan organisasi dan keinginan yang lebih besar untuk tetap bertahan di sebuah organisasi.

Komitmen terhadap organisasi menjadi sangat penting dalam kegiatan belajar mengajar karena dengan komitmen yang tinggi dapat menimbulkan keterikatan diri terhadap tugas dan kewajiban sebagai guru yang dapat melahirkan tanggung jawab dan menumbuhkan nilai responsif yang kreatif dalam proses mendidik anak. Komitmen terhadap organisasi yang berasal dari diri sendiri maka motivasi kerja akan timbul dengan sendirinya sehingga proses kegiatan belajar mengajarpun akan terlaksana dengan baik. Hal ini ditunjukan dengan semakin tinggi komitmen kerja guru maka semakin tinggi kinerja guru baik secara kuantitas maupun kualitas terhadap tugas dan tanggung jawabnya.

Berdasarkan hasil penelitian awal di Gugus II kecamatan Cipayung kota Depok, guru merasa bangga terhadap organisasi dan sayang terhadap peserta didik $59,55 \%$,. Aktif dalam pelatihan dan melaksanakan tugas dengan baik 50,9\%, Rela berkorban demi organisasi dan bersedia melebihi waktu rutinitas kerja 53,21\%, Berkeinginan untuk tetap bekerja senantiasa melaksanakan tugas tambahan 25,15\%, Mengutamakan kepenting sekolah dan memberikan pelayanan semaksimal mungkin 52,21\% ,. Keinginan untuk tetap bertahan dalam organisasi walaup un ada kesempatan yang lebih baik 44,26\%. Dari data tersebut dapat dilihat bahwa Komitmen Terhadap Organisasi guru Gugus II di Kecamatan Cipayung relatif masih rendah Oleh karena itu perlu diupayakan penelitian untuk mengetahui dan mengukur Komitmen Terhadap Organisasi guru dilihat dari faktor-faktor yang berhubungan dengan variabel Komitmen Terhadap Organisasi.

\section{METODE PENELITIAN}

Penelitian ini dilakukan di Gugus II kecamatan Cipayung, Kota Depok. Penelitian ini menggunakan teknik proporsional random sampling dengan jumlah sampel sebanyak 82 orang menggunakan rumus Slovin. Penelitian ini menggunakan metode survey dengan pendekatan korelasional yaitu jenis penelitian yang berupaya untuk menemukan ada tidaknya hubungan variabel bebas dengan satu variabel bebas yaitu Motivasi Kerja (X) serta satu variabel terikat yaitu Komitmen Terhadap Organisasi (Y). Uji persyaratan analisis data antara lain uji normalitas menggunakan uji Lilifors sedangkan untuk uji homogenitas menggunakan uji Bartlett. Data penelitian dianalisis menggunakan teknik korelasi sederhana, parsial dan ganda, serta menggunakan persamaan regresi linier sederhana dan ganda.

\section{HASIL DAN PEMBAHASAN}

\section{Pengujian Prasyarat Analisis}

1. Uji Normalitas Galat Baku Taksiran

Pengujian normalitas galat baku taksiran menggunakan uji Liliefors. Nilai $\mathrm{L}_{\text {tabel }}$ untuk $\mathrm{N}=82$ dengan $\alpha=0,05$ adalah 0,0978, pada taraf signifikansi 0,05 . Perhitungan uji normalitas galat baku taksiran $(\mathrm{Y}-\hat{\mathrm{Y}})$ variabel komitmen terhadap organisasi (Y) atas motivasi kerja (X) menghasilkan nilai $\mathrm{L}_{\text {hitung }}$ sebesar 0,065 Karena nilai $\mathrm{L}_{\text {hitung }}<\mathrm{L}_{\text {tabel}}$, pada taraf signifikansi 0,05 , dengan demikian dapat disimpulkan bahwa galat baku taksiran komitmen terhadap organisasi atas motivasi kerja berasal dari populasi yang berdistribusi normal.

\section{Uji Homogenitas}

Dari hasil perhitungan uji homogenitas dengan uji Bartlett variabel Komitmen Terhadap Organisasi (Y) atas variabel motivasi Kerja (X) menghasilkan nilai $\chi_{\text {hitung }}^{2}$ sebesar 17,77 sedangkan $\chi_{\text {tabel }}^{2}$ pada $\alpha=0,05$ adalah 66,36 Karena nilai $\chi_{\text {hitung }}^{2}<\chi_{\text {tabel, dengan demikian dapat }}^{2}$ disimpulkan bahwa kelompok data komitmen terhadap organisasi atas variabel motivasi kerja berasal dari populasi yang homogen.

\section{Pengujian Hipotesis}

Berdasarkan perhitungan uji kelinearan regresi, hubungan antara variabel terikat (Y) Komitmen terhadap organisasi dengan variabel bebas (X) motivasi kerja dinyatakan dalam persamaan regresi linier sederhana $\hat{Y}=$ $93,16+0,36 \mathrm{X}$. Hasil uji signifikasi persamaan regresi tersebut menunjukkan bahwa persamaan regresi $\hat{Y}=93,16+$ $0,36 \mathrm{X}$ tersebut sangat signifikan yang ditunjukkan dengan skor $F_{\text {hitung }}(16,29)>F_{\text {tabel }}(6,96)$. Hasil uji linieritas persamaan regresi menunjukkan persamaan regresi $\hat{\mathrm{Y}}=$ 93,16 + 0,36 X berbentuk linier sehingga rumus korelasi Product Moment Pearson dapat digunakan.

Hasil perhitungan koefisien korelasi $\left(\mathrm{r}_{\mathrm{y}}\right)$ menunjukkan bahwa terdapat hubungan positif antara Variabel Terikat (Y) Komitmen Terhadap Organisasi dengan Variabel Bebas (X) Motivasi Kerja dengan skor $r_{\mathrm{y}}$ adalah 
sebesar 0,411. Uji signifikasi korelasi menunjukkan hubungan kedua variabel signifikan dengan skor $t_{\text {hitung }}=$ $(4,04)$ lebih besar dari $t_{\text {tabel }}(1,66)$ pada taraf signifikansi 0,05 maupun $t_{\text {tabel }}(2,37)$. Hasil perhitungan koefisien korelasi dan uji signifikansi korelasi antara Variabel Terikat (Y) Komitmen Terhadap Organisasi dengan Variabel Bebas (X) Motivasi Kerja, dapat dilihat pada Tabel

Tabel 1. Hasil Perhitungan Koefisien Korelasi dan Uji Signifikansi Koefisien Korelasi antara Variabel Terikat (Y) Komitmen Terhadap Organisasi dengan Variabel Bebas (X) Motivasi Kerja.

\begin{tabular}{|c|c|c|c|c|c|}
\hline Dk & $\begin{array}{c}\text { Koefisien } \\
\text { Korelasi } \\
\left(\mathrm{r}_{\mathrm{y})}\right.\end{array}$ & $\mathrm{t}_{\text {hitung }}$ & \multicolumn{2}{|c|}{$\mathrm{t}_{\text {tabel }}$} & \multirow{2}{*}{ Kesimpulan } \\
\cline { 4 - 5 } & 0,506 & $4,04 * *$ & 1,66 & 2,37 & $\begin{array}{c}\text { Sangat } \\
\text { Signifikan }\end{array}$ \\
\hline
\end{tabular}

Hasil penelitian secara keseluruhan menunjukkan bahwa: terdapat hubungan positif yang sangat signifikan antara variabel $(\mathrm{X})$ motivasi kerja dengan variabel $(\mathrm{Y})$ komitmen terhadap organisasi. Model hubungan antara motivasi kerja dengan komitmen terhadap organisasi guru dinyatakan dalam persamaan regresi linier sederhana $\hat{\mathrm{Y}}=$ $93,16+0,36 X$, artinya setiap peningkatan satu unit nilai motivasi kerja akan menghasilkan komitmen terhadap organisasi sebesar 93,16. Tingkat hubungan (korelasi) antara motivasi kerja dengan komitmen terhadap organisasi sebesar 0,36 (36\%) unit dengan konstantan 93,16. Persamaan regresi $\hat{\mathrm{Y}}=96,16+0,36 \mathrm{X}$ dapat digunakan untuk memprediksi skor komitmen terhadap organisasi jika skor motivasi kerja diketahui. Nilai koefisien korelasi $\left(\mathrm{r}_{\mathrm{y}}\right)$ adalah sebesar 0,411 menunjukkan hubungan yang positif antara motivasi kerja dengan komitmen terhadap organisasi. Kontribusi motivasi kerja terhadap komitmen terhadap organisasi ditunjukkan oleh nilai koefisien determinasi $\left(\mathrm{r}_{\mathrm{y}}{ }^{2}\right)$ sebesar 0,169 yang berarti $16,9 \%$ variasi komitmen terhadap organisasi (Y) dapat dijelaskan oleh variasi motivasi kerja (X) melalui persamaan regresi $\hat{\mathrm{Y}}=93,16+0,36 \mathrm{X}$.

Kontribusi motivasi kerja terhadap komitmen terhadap organisasi sebesar 16,9\% Dengan demikian komitmen terhadap organisasi akan terwujud bila dipengaruhi oleh tingkat motivasi kerja.

\section{SIMPULAN}

Adapun hasil penghitungan analisis data dan pengujian hipotesis, maka dapat disimpulkan hasil penelitian terdapat hubungan positif yang sangat signifikan antara motivasi kerja dengan komitmen terhadap organisasi. Hubungan fungsional antara motivasi kerja dengan komitmen terhadap organisasi disajikan dalam bentuk persamaan regresi $\hat{\mathrm{Y}}=$ $93,16+0,36 X$. Persamaan regresi tersebut berarti bahwa setiap penambahan satu skor variabel motivasi kerja akan menyebabkan kenaikan komitmen terhadap organisasi sebesar 0,36 dengan konstanta 93,16. Nilai koefien korelasi $\left(r_{y}\right)$ sebesar 0,411 (hubungan cukup kuat positif) dengan koefisien determinasi sebesar 0,169 berarti kontribusi motivasi kerja terhadap komitmen terhadap organisasi sebesar $16,9 \%$. Berdasarkan temuan penelitian tersebut, dapat disimpulkan bahwa terdapat hubungan positif antara motivasi kerja dengan komitmen terhadap organisasi guru Gugus II di Kecamatan Cipayung Kota Depok.

\section{REFERENSI}

[1] Wibowo. 2012. Manajemen Perubahan, Jakarta: PT. Raja Grafindo Persada,.

[2] Prayitno. 2009. Dasar Teori dan Praktis Pendidikan, Jakarta: PT Gramedia,

[3] Stephen P. Robbins dan Timothy A Judge. 2008. Perilaku Organisasi, terjemahan Diana Angelica, Jakarta: salemba Empat,.

[4] Fred Luthans. 2011. Organizational Behavior: An Evidence-Based Approach $12^{\text {th }}$ Edition, New York: McGraw-Hill Irwin,.

[5] Robert Kreitner dan Angelo Kinicki. 2008. Organizational Behavior, New York: McGraw-Hill Irwin,. 